\title{
The Impact of Organizational Change on Employees Psychological Contract Breach in the Nigerian Oil and Gas Industry
}

\author{
Marian Lawrence Apoh \\ Faculty of Management Sciences, Niger Delta University, Bayelsa, Nigeria
}

\begin{abstract}
This study examined the impact of organizational change on employees' psychological contract breach in the Nigerian oil and gas industry. The cross-sectional survey was adopted and data was drawn from 322 employees of various oil and gas companies in Nigeria. The findings statistically showed a non-significant relationship between organizational change and employees' psychological contract breach. These findings reveal the importance of employees' level of commitment, job satisfaction and the type of sector employees' work for. The findings are thereafter discussed with conclusions and recommendations.
\end{abstract}

Keywords: Organisational Change, Employees Psychological Contract Breach, Confirmatory Factor Analysis, Nigeria

DOI: $10.7176 / \mathrm{EJBM} / 11-23-11$

Publication date: August $31^{\text {st }} 2019$

\section{Introduction}

The Nigerian oil and gas industry is one of the biggest in the continent of Africa (Mbah and Ikemefuna, 2012). The oil and gas industry constitute a major source of income for the nation. The industry contributes 35 per cent of GDP and $95 \%$ of foreign exchange earnings. The oil reserve is estimated at 36 billion barrels and is expected to last for another 30 years (Mbah and Ikemefuna, 2012). The earnings help the Nigerian government to embark on major projects such as roads, schools, hospitals and granting of scholarships. It should be noted however that this laudable prospect of the industry would not be achieved without an appropriate employer-employee relationship.

The relationship between employees and their employers is seen as involving a psychological contract which is a series of mutual expectations that employees bring to the organization of which the employer may not be fully aware but which nonetheless govern their relationship to each other (Parzefall and Coyle-Shapiro, 2011; Restubog et al., 2011). Psychological contracts are formed on the basis of perceived promises and obligations that arise from implicit (e.g., organisational practices and policies) or explicit (e.g., verbal statements and written documents) and is seen as an important factor in understanding employment relationships (Conway and Briner, 2005; Parzefall and Hakanen, 2010; Bal et al., 2013; Rayton and Yalabik, 2014). However, in most cases these perceived promises are not fulfilled, meaning a 'breach of contract'. According to Morrison and Robinson (1997: 230), a psychological contract breach can be defined as "the cognition that one's organisation has failed to meet one or more expectations, promises and obligations within a psychological contract".

Psychological contract breach is most likely to occur during times of organizational change. Organizations that are under pressure to make rapid and constant changes have had to alter employment relationships and the psychological contracts that bind them (Agarwal, 2011; Agarwal and Bhargava, 2013). The terms of the employment agreement are being repeatedly renegotiated and altered to fit changing circumstances (Chaudhry et al., 2011; Parzefall and Coyle-Shapiro, 2011; Chiang et al., 2012), and employers may become less willing and/or less able to fulfil all of their promises and obligations to employees.

\section{Literature Review}

\subsection{Employees Psychological Contract Breach}

Psychological contract evolves as the employment relationship changes and one of the main focuses is the research on psychological contract breach (Robinson and Rousseau, 1994; Morrison and Robinson, 1997). Organisations are downsizing, restructuring, and in many ways not fulfilling the perceived obligations that employees feel their organisations have for them (Guest and Conway, 2000; Robinson and Morrison, 2000). These organisational changes often make the employment relationship uncertain (Guest and Conway, 2004). Psychological contracts, involving employee beliefs about reciprocal obligations between themselves and their organisations, are the foundation of employment relationships (Garrow, 2005). As employees interact with managers and observe organisational procedures, they develop beliefs about what they owe to their organisation as well as how the organisation is obligated to reciprocate their efforts and actions (Lester et al., 2007; Chen et al., 2008). However, organisations may sometimes not be able or willing to fulfil all of the obligations made to their employees, resulting in psychological contract breach (Dulac et al., 2008; Conway and Briner, 2009; Restubog et al., 2013; Zagenczyk 
et al., 2014).

Psychological contract breach occurs when employees perceive a discrepancy between what they were promised and what they actually received from the organisation (Morrison and Robinson, 1997). The idea of a perceived contract breach varies from person to person because it all depends on each employee's expectations, reasoning and interpretation. The dynamic and subjective nature of psychological contracts makes it challenging to fulfil the perceived obligation (Coyle-Shapiro and Kessler, 2000; Gakovic and Tetrick, 2003). Therefore, breach is essentially the identification of perceived unmet obligations which may lead to emotional reactions and affects individual's belief in the reciprocal employment relationship (Pate et al., 2003; De Cuyper et al., 2008a; Conway and Briner, 2009; Cassar and Briner, 2011; Cassar et al., 2013).

Also, Robinson and Morrison (2000) suggested that psychological contract breach signifies the employees' cognitive valuation of one's organisation fulfilment of the psychological contract. Accordingly, Coyle-Shapiro and Kessler (2000) and Agarwal (2011) argued that psychological contract breach captures employees' cognitive opinion of what they have received from what they were promised, indicating the level of fulfilment of the psychological contract by their organisation.

\subsection{Organisational Change}

Research studies from different management disciplines use various terms to define organisational change and diverse adjectives to explain the nature of change (Armenakis and Bedeian, 1999; Terry and Jimmieson, 2003; Oreg, 2006; Armenakis and Harris, 2009; Bezboruah, 2008; Bamberger et al., 2012). Organisational change has become inevitable for organisations as business environments become increasingly volatile due to globalisation (Liu et al., 2012) and as a result, organisations effect changes such as the modernisation of office operating systems, establishment of new work processes to leadership changes and the implementation of reorganisations or relocations (Michel et al., 2013). Organisational change implies a fundamental organisation-wide transformation that an organization undergoes in reaction to a changing business environment, as opposed to minor organisational alterations such as addition of new personnel, modification of a specific programme, or establishing a new technical procedure (Pettigrew et al., 2001; Shore et al., 2004; Sronce and McKinley, 2006; Carter et al., 2013). Organisational change is a process that organisations pursue to align their core business aspects in order to be flexible enough to anticipate, adapt and respond to demanding global trends (Chaudhry et al., 2011). For an organisation to be adaptive and responsive, it requires a strategic shift in directions which subsequently affects the way it operates. In other words, organisational change can be viewed as an organisation's response to significant pressures and forces arising from an internal and external environment in order to increase value and improve corporate effectiveness (Terry and Jimmieson, 2003; Paulsen et al., 2005; Malopinsky and Osman, 2006; Oreg, 2006). In support of these assertions, Dillard et al., (2011) defined organisational change as a combination of external and internal forces acting on the organisation and the organisation, in turn, influence the environment within which it operates.

Van de Ven and Poole (1995: 512) defined organizational change as "an empirical observation of difference in form, quality, or state over time in an organisational entity. The entity may be an individual's job, a work group, an organisational strategy, a program, a product, or the overall organisation". Also, Kovoor-Misra (2009) defined organisational change as a planned or unplanned transformation in the structure, technology and/or people in the organisation. In addition, Allen (2009: 18) organisational change is a "set of values, strategies, and techniques aimed at the planned change of the organisational work setting for the purpose of enhancing individual development and improving organisational performance, through the alterations of organisational members' onthe-job behaviour".

\subsection{Theoretical Framework}

The social exchange theory has generally been used in explaining the impact of psychological contract breach on employees' attitudes and behaviours (Turnley et al., 2003). In the employment relationship, the two parties in the exchange relationship give noticeable paybacks such as rewards and money and/or unnoticeable paybacks such as socio-emotional supports (Sturges et al., 2005; Agarwal and Bhargava, 2013). However, these paybacks are a form of reciprocity; in that one party in the employment relationship is expected to reciprocate by way of giving back to the other party, thereby strengthening the interpersonal relationship (Cropanzano and Mitchell, 2005; Chaudhry and Tekleab, 2013).Each employee in an organisation seeks to create and retain an impartial and balanced exchange relationship with other co-workers. But when employees perceive that there is an imbalance between what they were promised and what was actually received from their organisation, then a breach to psychological contract is likely to have occurred (Cropanzano and Mitchell, 2005; Zhao et al., 2007; Conway and Coyle-Shapiro, 2012; Chaudhry and Tekleab, 2013).

\subsection{Relationship Between OC and EPCB}

Employees may possibly react in a number of ways, when confronted with difficult or unfavourable organisational 
circumstances such as organisational change. They may wait for conditions to improve or support the organisation. Also, they may reduce their effort, use company time for personal business, or exhibit withdrawal behaviours such as lateness or absences. Employees' attitudes and behavioural options, capable of transforming the conditions from negative to positive (or from positive to negative), profoundly impact organisational well-being and effectiveness.

Organisational changes are presumed to have an impact on employees' psychological contract because the changes are likely to affect what the organisation will offer to the employees and/or what the organisation expects to receive from its employees (Freese et al., 2011; Cartwright and Cooper, 2013). Psychological contracts are assumed to be influenced by organisational changes in a number of ways. In the first place, the change itself may have consequences for the work situation of employees, for example when their role and tasks are affected, and they have to adapt to new circumstances and changed demands (Chaudhry et al., 2011; Michel and GonzálezMorales, 2013; Cronin and McGuinness, 2014). Therefore, based on the literature review and empirical studies, organisational change is expected to be significantly related to psychological contract breach. Thus, the following hypothesis is proposed:

H1: Organisational change will be significantly related to employees' psychological contract breach in the Nigerian oil and gas industry.

\section{Research Methodology}

Cross-sectional, likert 5-point written scale from 1 strongly disagree to 5 strongly agree.

\subsection{Questionnaire}

The variables and the measurements used were either developed from the relevant literature or adopted from other studies. Section A comprises 34 items (A1-A34), it contains information about psychological contract breach. Various contents items of the psychological contract such as pay and income, steady job, and career development opportunities in which each participant indicates the extent to which his/her organisation had fulfilled its obligations to them regarding each item. All of the respondents' choices on each item are reverse scored so that higher scores reflect stronger psychological contract breach (Turnley and Feldman, 1999; Zhao et al., 2007; Montes and Irving, 2008). The contents items in previous studies were largely adopted in this study (Rousseau, 2000; McDonald and Makin, 2000; Hui et al., 2004). Rousseau (2000) developed a Psychological Contract Inventory (PCI) as a tool for measuring the perceived fulfilment of the psychological contract. Thus, the 12 items for measuring the fulfilment of the psychological contract are originally based on Rousseau's (2000) scales. However, the items in Rousseau's (2000) scales are not completely suitable because this study focuses on the Nigerian oil and gas employees' context. Through the informal interviews and discussion with the Nigerian oil and gas employees, the item of 'Recognition of contributions to the organization' in McDonald and Makin's (2000) study and the items of 'Support me to achieve the highest possible level of performance' and 'Skill development that increases my value to this organisation' in Hui et al., (2004) were added to the questionnaire.

Section B of the survey questionnaire comprises 19 items (C1 to C19). In accordance with the objectives of the research, this section contains the information about organisational changes employees in the Nigerian oil and gas companies had experienced in the past ten years. It was tested using a measure developed for this study. This was based on the concept found in the literature, which resulted in a 19 item scale being used to measure organszational change. Also, information gathered through the review of literature, informal interviews and conversations with employees in the oil and gas industry were applied to develop a questionnaire for measuring organisational change.

\subsection{Pilot Study}

A pilot study was conducted to measure the reliability and validity of the questionnaire before the main study. Prior to using the questionnaire to collect data it was pilot tested. The purpose of the pilot test was to improve the questionnaire in that participants will not have difficulty answering the questions. Upon completion of the study, the data were coded and entered on to the statistical package for social sciences (SPSS) version 22.0 for Windows. After exploratory factor analysis, factors were confirmed via confirmatory factor analysis on the basis of structural equation modelling (SEM).

\subsection{Questionnaire and Data Collection}

A total of 600 questionnaires were distributed to a randomly selected sample of employees from various levels (i.e. senior managers, middle managers, junior managers and others involving clerical assistants, security, contract staffs, cleaners, etc). A total of 322 usable questionnaires were received giving a response rate of $52 \%$. The tools employed in analysing the data collected are descriptive statistics and factor analysis, using Analysis of Moments of Structure (AMOS 22.0) for windows. 


\subsection{Data Analysis Statistical Techniques}

Structural equation modelling (SEM) analysis technique was used to analyse the relationship between organisational change and the Nigerian oil and gas employee's psychological contract breach. In this study, the use of SEM involves a two steps approach: first, it was used to evaluate the measurement models and then evaluate the structural model. Both the exploratory factor analysis (EFA) and the confirmatory factor analysis (CFA) were undertaken in order to evaluate the measurement models. EFA is a method used to load factors into groups in order to extract underlying latent factors. It is a technique used to "take what the data gives you" (Hair et al, 2006: 104) and group variables together on a factor or a specific number of factors. It is generally conducted before testing the research hypotheses and used to identify the latent factors, summarise and reduce a large number of observed variables to a smaller set of factors (Hair et al., 2010; Williams and Brown, 2013). This technique is effective for further testing of structural models (Field, 2009; Hair et al., 2010; Preacher et al, 2013). Absolute fit measures such as the maximum likelihood estimation (CMIN/DF), Goodness-of-fit Index (GFI), Adjusted Goodness-of-fit Index (AGFI), Comparative Fit Index (CFI), Incremental Fit Index (IFI) and Root Mean Square Error of Approximation (RMSEA) were used to determine the quality of the overall fit of the measurement model and the distribution of the covariance matrix fit indices used to evaluate the results (Byrne, 2001; 2010). These measures of fit were selected because they were the most highly recommended fit indices (Burnett and Williams, 2005) and a review of relevant literature revealed that these measures were the most often used when analysing similar data. AMOS software 22.0 was used to evaluate the structural model.

\subsection{Validity and Reliability}

For reliability assessment, Cronbach's alpha technique was applied to the factors derived from the exploratory factor analysis to test the internal consistency of factors (Churchill, 1979; Peter, 1979; Litwin, 1995; De Vaus, 2002). Result values equal to or above 0.70 were considered to be an acceptable level of reliability (Nunnally, 1978; De Vaus, 2002). By using the SPSS statistical package, data from the questionnaire was tested. The results of this study show that the alpha score for all the factors in the questionnaire was higher than .60. Thus, the questionnaire used in this research is considered reliable. After measuring the reliability and validity of the instrument, it was applied to collect data for the main study in Nigeria.

\section{Findings}

This section presents the findings on the impact of organisational change on Nigerian oil and gas employees' psychological contract breach, which is one of the research objectives of this study. The relevant factor analysis for psychological contract breach was undertaken and thereafter their correlations were examined. The factor analysis for organisational change was carried out and explained in the previous section. Also, a Kaiser-MeyerOlkin Measure of Sampling Adequacy and Bartlett's Test of Sphericity was undertaken to test if it was appropriate to conduct a factor analysis on the items in the questionnaire.

Table 1: Kaiser-Meyer-Olkin Measure of Sampling Adequacy and Bartlett's Test on Psychological Contra

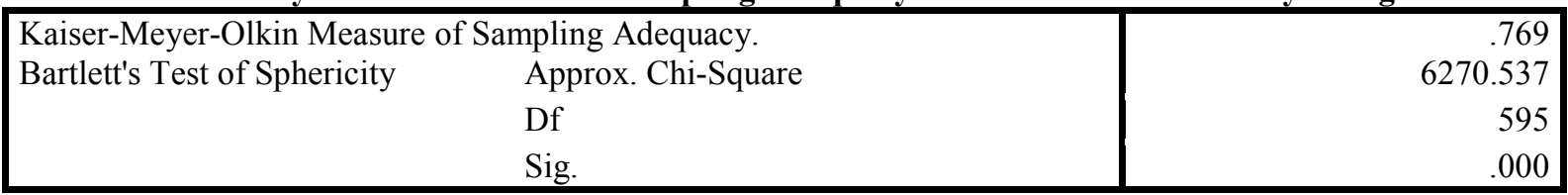

The results on Table 1 above indicate that the value of Kaiser-Meyer-Olkin Measure of Sampling Adequacy was .769. Also, the result of the Bartlett's Test of Sphericity is significant at the level of (.000), which is considered valid and suitable to carry out the relevant factor analysis. Further, a total variance test was carried out to test the construct validity of the items in measuring psychological contract breach. According to Kerlinger and Lee (2000), the value for the rotation sums of squared loadings should be more than 0.50 in confirming the construct validity of the items in the questionnaire.

The results on Table 2 below show the rotated component matrix of the total variance test. Principal Component Analysis showed the presence of three components with eigenvalues above 1. The 'total' for component 1 is 6.952 , which explains the variance of $19.862 \%$; the 'total' for component 2 is 2.857 , which explains the variance of $8.163 \%$; the 'total' for component 3 is 1.952 , which explains the variance of 5.576; and the cumulative percentage was 33.601\%. The results from the Principal Component Analysis revealed that it was appropriate to perform a factor analysis on the components in the questionnaire relating to the Nigerian oil and gas employees' psychological contract breach. An exploratory factor analysis (i.e. varimax rotation) was then carried out on the components relating to the Nigerian oil and gas employees' psychological contract breach.

The results of the varimax rotation factor loadings grouped the Nigerian oil and gas employees' psychological contract breach into transactional psychological contract breach, relational psychological contract breach and balanced psychological contract breach (Table 2). 
Table 2: Total Variance Explained on the Dimensions of Psychological Contract Breach

\begin{tabular}{|c|c|c|c|c|c|c|c|c|c|}
\hline & \multicolumn{2}{|c|}{$\begin{array}{l}\text { Initial } \\
\text { Eigenvalues }\end{array}$} & \multicolumn{4}{|c|}{$\begin{array}{l}\text { Extraction Sums of Squared } \\
\text { Loadings }\end{array}$} & \multicolumn{3}{|c|}{$\begin{array}{llll}\text { Rotation } & \text { Sums of } \\
\text { Loadings } & & & \\
\end{array}$} \\
\hline Component & 吾 & 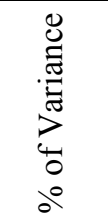 & 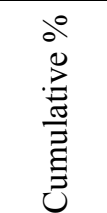 & 预 & 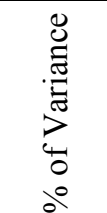 & 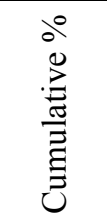 & 吾 & 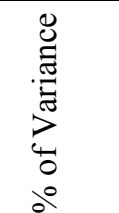 & 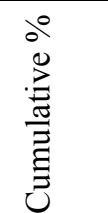 \\
\hline $\begin{array}{l}\text { Transactional } \\
\text { PCB }\end{array}$ & 6.952 & 19.862 & 19.862 & 6.952 & 19.862 & 19.862 & 5.102 & 14.579 & 14.579 \\
\hline Relational PCB & 2.857 & 8.163 & 28.025 & 2.857 & 8.163 & 28.025 & 4.076 & 11.646 & 26.225 \\
\hline Balanced PCB & 1.952 & 5.576 & 33.601 & 1.952 & 5.576 & 33.601 & 2.582 & 7.376 & 33.601 \\
\hline
\end{tabular}

Extraction Method: Principal Component Analysis Exploratory Factor Analysis on Nigerian Oil and Gas Employees' Psychological Contract Breach

The results on Table 3 below show a three factor structure which includes relational psychological contract breach, transactional psychological contract breach and balanced psychological contract breach. The results of the varimax rotation factor loadings grouped Nigerian oil and gas employees' psychological contract into three types of contract breach. Each contract breach was loaded a set of components as seen from the Table. Further, each loaded factor was assessed by Cronbach's alpha to test the reliability of the factor. The Cronbach's alpha result for the factors was $.92, .87$, and .96 which showed that it exceeded the recommended threshold of .80 for acceptance (Pai et al., 2011).

Table 3: Results of Exploratory Factor Analysis on Psychological Contract Breach

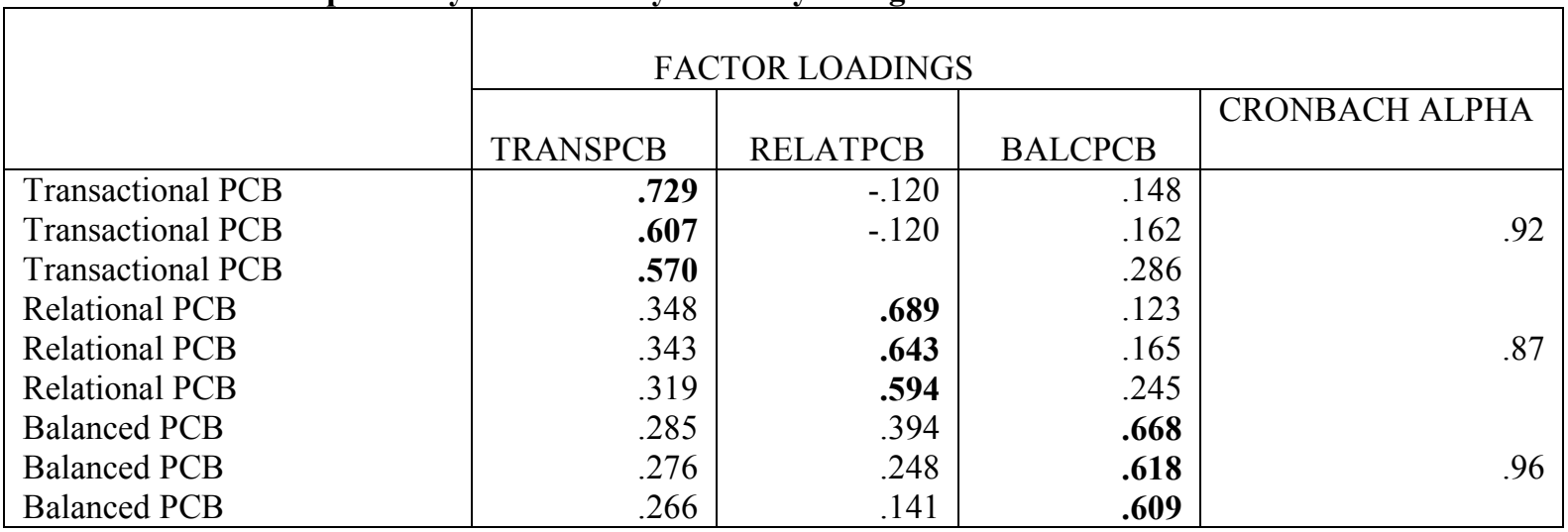

Extraction Method: Principal Component Analysis, Rotation Method: Varimax with Kaiser Normalization Confirmatory Factor Analysis on Nigerian Oil and Gas Employees' Psychological Contract Breach

A confirmatory factor analysis was carried out to test the measurement model of the Nigerian oil and gas employees' psychological contract breach. The results on Table 4 below show the path coefficients factors and correlations between the dimensions of psychological contract breach. The results show that the correlations between those factors are significant at the level of $(p<.05)$. This indicates that the model fitting index of the Nigerian oil and gas employees' psychological contract breach is acceptable and valid.

Table 4: Correlations between the Dimensions of Psychological Contract Breach

\begin{tabular}{|lcc|cccc|}
\hline & & & Estimate & S.E. & C.R. & P \\
\hline TRANSPCB & $<->$ & RELATPCB & .367 & .048 & 7.710 & $* * *$ \\
TRANSPCB & $<-->$ & BALCPCB & -.298 & .042 & -7.025 & $* * *$ \\
RELATPCB & $<-->$ & BALCPCB & -.362 & .047 & -7.638 & $* * *$ \\
\hline
\end{tabular}

TRANSPCB $=$ transactional psychological contract breach, RELATPCB $=$ relational psychological contract breach, BALCPCB= balanced psychological contract breach.

The results on Table 5 below show the measurement model fitting index of the Nigerian oil and gas employees' psychological contract breach. Fit indices of model $(\mathrm{CMIN} / \mathrm{DF}=2.843 ; \mathrm{RMSEA}=.059 ; \mathrm{GFI}=.954, \mathrm{AGFI}=.919$, $\mathrm{IFI}=.943, \mathrm{NFI}=.914, \mathrm{TLI}=.910$ and $\mathrm{CFI}=.942$ ). Based on the general recommended value for an acceptable model; the fitting model index of the second-order analysis on the Nigerian oil and gas employees' psychological contract breach showed a perfect model fit. All the values are above the range of .90 meaning it is well fitted. Thus, 
it is considered reasonable and acceptable (Bagozzi et al., 1991; Doll et al., 1994; Mueller, 1996; Hair et al., 2011). Table 5: Model Fitting Index on the Measurement Model of the Nigerian Oil and Gas Employees' Psychological Contract Breach

\begin{tabular}{|l|l|l|l|l|l|l|l|}
\hline CMIN/DF & RMSEA & GFI & AGFI & IFI & NFI & TLI & CFI \\
\hline 2.843 & .059 & .954 & .919 & .943 & .914 & .910 & .942 \\
\hline
\end{tabular}

The results on Table 6 below show that the level of the measurement model fit of the Nigerian oil and gas employees' psychological contract breach is satisfied (CMIN/DF=2.242, RMSEA=.059, GFI=963, AGFI=921, $\mathrm{IFI}=939, \mathrm{NFI}=922, \mathrm{TLI}=915, \mathrm{CFI}=939$ ). The RMSEA measure is within the acceptable range of 0.05 and 0.08 (Garver and Mentzer, 1999), NFI, and CFI were above the 0.90 threshold value and GFI and AGFI were above the recommended value of 0.90 (Bagozzi et al., 1991; Doll et al., 1994; Mueller, 1996; Garver and Mentzer, 1999; Hair et al., 2011). Thus, the measurement model for the second-order confirmatory factor analysis on the Nigerian oil and gas employees' psychological contract breach is acceptable and valid.

Table 6: Model Fitting Index for the Second-order Analysis for the Nigerian Oil and Gas Employees' Psychological Contract Breach

\begin{tabular}{|l|l|l|l|l|l|l|l|}
\hline CMIN/DF & RMSEA & GFI & AGFI & IFI & NFI & TLI & CFI \\
\hline 2.242 & .059 & .963 & .921 & .939 & .922 & .915 & .939 \\
\hline
\end{tabular}

The Structural Equation Modelling between Organisational Change and Psychological Contract Breach of the Nigerian oil and gas Employees.

Table 7 below show the results of the model fitting index of the dimensions of organisational change and the Nigerian oil and gas employees' psychological contract breach. The results indicate that the model fit is acceptable and valid. Fit indices of model $(\mathrm{CMIN} / \mathrm{DF}=1.705 ; \mathrm{RMSEA}=.043 ; \mathrm{GFI}=.948, \mathrm{AGFI}=.926, \mathrm{IFI}=.930, \mathrm{NFI}$ $=.902, \mathrm{TLI}=.914$ and CFI $=.929)$. Based on the general recommended value for an acceptable model, the relational model between organisational change and the Nigerian oil and gas employees' psychological contract breach is confirmed and acceptable. This is because all the values are above the suggested range of 0.90 which is an indication that it is well fitted.

Table 7: Model Fitting Index on the Relational Model between Organisational Change and Nigerian Oil and Gas Employees' Psychological Contract Breach

\begin{tabular}{|l|l|l|l|l|l|l|l|}
\hline CMIN/DF & RMSEA & GFI & AGFI & IFI & NFI & TLI & CFI \\
\hline 1.705 & .043 & .948 & .926 & .930 & .902 & .914 & .929 \\
\hline
\end{tabular}

The results on Table 8 below show that organisational change is positively correlated to the Nigerian oil and gas employees' psychological contract breach at .979 and at a p-value of .193 which means it is positive but not significant at $\mathrm{p}<.05$. This means that organisational change do not have an influence on employees' psychological contract breach in the Nigerian oil and gas companies.

Table 8: Regression Weights between Organisational Change and Nigerian Oil and Gas Employees' Psychological Contract Breach

\begin{tabular}{|c|c|c|c|c|c|c|}
\hline & & & Estimate & S.E. & C.R. & $\mathrm{P}$ \\
\hline PCB & $<---$ & Organisational change & .979 & .330 & .026 & .193 \\
\hline
\end{tabular}

Therefore, based on the results above, the Hypothesis H1 is not supported:

H1: Organisational change will be significantly related to employees' psychological contract breach in the Nigerian oil and gas industry is not supported.

In summary, the findings in this study shows that there was no significant relationship between organisational change and employees' psychological contract breach in the Nigerian oil and gas companies. This invariably means that organisational change do not have an influence on employees' psychological contract breach in the Nigerian oil and gas companies.

\section{Discussion}

The study hypothesis investigated the relationship between organisational change and the Nigerian oil and gas employees' psychological contract breach. It was found that there was no significant relationship between organisational change and the Nigerian oil and gas employees' psychological contract breach. These findings are not in support of previous theoretical and empirical studies that found a significant relationship between organisational change and employees' psychological contract breach (Morrison, 1994; Turnley and Feldman, 1998; Robinson and Morrison, 2000; Lo and Aryee, 2003; Bellow, 2007). This could mean that organisational change simply does not have a significant impact on the Nigerian oil and gas employee psychological contract breach. The possible explanation for this could be that job security may have moderated the non-significant relationships between psychological contract breach and organizational changes in the Nigerian oil and gas companies. Employees are feeling stuck in their jobs because of the few employment opportunities outside of their present job in the context of rising unemployment in Nigeria. This would make employees in the Nigerian oil and gas 
companies to react to psychological contract breach by increasing their work efforts and demonstrating their value through increased performance to the organisation. This argument is supported by research suggesting that anxiety about layoffs can increase performance in the short term (Brockner et al., 1986). Staufenbiel and König (2010) and Ye et al., (2012) found a strong relationship between job insecurity, organisational citizenship behaviour and psychological contract breach. Also, Conway et al., (2014) found that employees with secured job experiencing psychological contract breach increased performance behaviour. This means that employees in the Nigerian oil and gas companies for the fear of losing their present job, they will put away neglect behaviours following breach, as they suspect that neglect behaviour would likely lead to redundancy. Employees in the Nigerian oil and gas companies would likewise withdraw negative behaviours, as research shows that undertaking organisational citizenship behaviour towards the organisation influences managers' decisions in allocating rewards (Mbah and Ikemefuna, 2012).

Another possible explanation of the non-significant relationship between organisational change and psychological contract breach could be employees' level of commitment to their job and job satisfaction. Job satisfaction is seen as a major factor for employees in the Nigerian oil and gas companies. This can be attributed to the promotion opportunities, good working relationship with co-workers, and good quality working conditions compared to their colleagues in other organisations. Also, it can be attributed to high responsibilities, job autonomy and interest that employees in the Nigerian oil and gas companies attached to their job. The above explanation is supported by previous studies carried out in other countries. For example, Ellickson and Logsdon (2001) found that promotional opportunities were positively related to employees' job satisfaction. Also, Al-Enezi's (2000) found that employees who have good and harmonious working relations with their co-workers experienced job satisfaction. Similarly, Metwally's (2002) found that good and suitable working conditions are key positive determinant of employees' job satisfaction. Antonaki and Trivella (2014) found high responsibilities, high autonomy and interests attached to the job as predictors of job satisfaction. Also, quality of work conditions, treatment with respect and fairness are strong indicators of employees' organisational commitment and job satisfaction.

\section{Conclusion}

It can be concluded from the foregoing discussion that there is no significant relationship between organisational change and employee's psychological contract breach in the Nigerian oil and gas companies. They do not show any counterproductive behaviour but rather engage in organisational citizenship behaviours and high level of commitment to their job tasks, managers and organisations. This could be because of the fear of losing their wellpaid jobs and the high rate of unemployment and may be a major determinant of good employee relationships that lead to the successful introduction of organizational changes in the Nigerian oil and gas companies. This study revealed employees behavioural responses to organisational changes which can be helpful in satisfying workplace needs and work behaviours research. It can be a support to managers, change agents and practitioners in assessing, designing and evaluating new and existing organisational change programmes.

\section{Recommendation}

The results of this study cannot and should not be generalized because the research was limited to Port Harcourt, Lagos and Abuja. Also, the use of a quantitative approach in data collection might have omitted vital information that captures the opinions and feelings of employees. Future research should consider a mixed research method approach for in-depth understanding of the relationship between organisational changes and employee psychological contract breach. However, despite the limitation, the study has contributed to knowledge in the fields of organisational change in the context of a developing country, which is Nigeria. Therefore, it is recommended that organisations in the Nigerian oil and gas industry should engage their employees more by increasing their level of involvement in decision making process and the process of implementing organisational changes. However, these effects may be reversed if management encourages employee-directed organisational changes by conveying that they are open to suggestions and contributions from employees and by acting in a way that demonstrates this openness which can increase organisational learning in the Nigerian oil and gas companies.

\section{References}

Agarwal, P. (2011) Relationship between Psychological Contract and Organizational Commitment in Indian IT Industry. The Indian Journal of Industrial Relations, 47(2),290-305.

Agarwal, U. A. \& Bhargava, S. (2013) Effects of psychological contract breach on organizational outcomes: moderating role of tenure and educational levels.Vikalpa, 38(1),13-25.

Aiken, L. S (2003) Multiple regression analysis. Sage, London.

Allen, M. R. (2009) The affect of organizational change by type and frequency on employee psychological contracts (Doctoral dissertation, Capella University).

Anderson, J. \& Gerbing, D. (1988) Structural Equation Modelling in Practice: A review and Recommended Two- 
step Approach. Psychological bulletin.103(3),411-423.

Antonaki, X. E. \& Trivellas, P. (2014) Psychological Contract Breach and Organizational Commitment in the Greek Banking Sector: The Mediation Effect of Job Satisfaction. Procedia-Social and Behavioral Sciences, 148,354-361.

Armenakis, A. A. \& Harris, S. G. (2009) Reflections: Our journey in organizational change research and practice. Journal of Change Management, 9(2),127-142.

Bagozzi, R., Yi, Y., \& Philips, L. (1991) Assessing Construct Validity in Organizational Research", Administrative Science Quarterly, 36(3),421-458.

Bal, P. M., Lange, A. H., Jansen, P. G., \& Velde, M. E. (2013) A longitudinal study of Age - Related differences in reactions to psychological contract breach. Applied Psychology. 62(1),157-181.

Bentler, P. M. \& Bonnett, D. G. (1980) Significance tests and goodness of fit in the analysis of covariance structures", Psychological bulletin. 88,588-606.

Bentler, P. M. (1990) Comparative fit indices in structural models. Psychological Bulletin. 107,238-246.

Bezboruah, K. C. (2008) Applying the congruence model of organisational change in explaining the change in the Indian economic policies. Journal of Organisational Transformation and Social Change, 5(2),129-140.

Byrne, B. M. (2001) Structural equation modelling with AMOS: Basic concepts, applications, and programming. Mahwah, NJ: Lawrence Erlbaum.

Byrne, B. M. (2010) Structural equation modelling with AMOS: Basic concepts, applications, and programming. New York, NJ: Taylor and Francis Group, LLC.

Cassar, V. \& Briner, R. B. (2011) The relationship between psychological contract breach and organizational commitment: Exchange imbalance as a moderator of the mediating role of violation. Journal of Vocational Behavior, 78(2),283-289.

Cassar, V., Buttigieg, S. C., \& Briner, R. B. (2013) Causal explanations of psychological contract breach characteristics. The Psychologist-Manager Journal, 16(2),85.

Chaudhry, A., Coyle-Shapiro, J., \& Wayne, S. (2011) A longitudinal study of the impact of organizational change on transactional, relational and balanced psychological contracts. Journal of leadership and organizational studies, 18(2),47-259.

Conway, N. \& Briner, R. (2005) Understanding Psychological Contracts at Work: A Critical Evaluation of Theory and Research. Oxford: Oxford University Press.

Conway, N. \& Briner, R. B. (2009) Fifty years of psychological contract research: What do we know and what are the main challenges. International review of industrial and organizational psychology, 24(71),71-131.

Coyle-Shapiro, J. A. \& Kessler, I. (2000) Consequences of the psychological contract for the employment relationship: A large scale survey. Journal of management studies, 37(7),903-930.

Cropanzano, R. \& Mitchell, M. S. (2005) Social exchange theory: An interdisciplinary review. Journal of Management, 31,874-900.

De Cuyper, N., De Jong, J., De Witte, H., Isaksson, K., Rigotti, T., \& Schalk, R. (2008b) Literature review of theory and research on the psychological impact of temporary employment: Towards a conceptual model. International Journal of Management Reviews, 10,25-51.

Dillard, J., Rogers, R., \& Yuthas K. (2011) Organizational change: in search of the golden mean. Journal of Accounting \& Organizational Change, 7(1),5-32.

Dulac, T., Coyle-Shapiro, J. A., Henderson, D. J., \& Wayne, S. J. (2008) Not all responses to breach are the same: The interconnection of social exchange and psychological contract processes in organizations. Academy of Management Journal, 51(6),1079-1098.

Field, A. (2013) Discovering statistics using IBM SPSS statistics. Sage.

Freese, C., Schalk, R., \& Croon, M. (2011) The impact of organizational changes on psychological contracts: A longitudinal study. Personnel Review, 40(4),404-422.

Garver, M. S. \& Mentzer, J. T. (1999) Logistic research methods: Employing structural equation modeling to test for construct validity. Journal of Business Logistic. 20(1),33-57.

Hair, J., Black, W., Babin, B., \& Anderson, R. (2010) Multivariate data analysis (7th ed.): Prentice-Hall, Inc. Upper Saddle River, NJ, USA.

Hui, C., Lee, C., \& Rousseau, D. M. (2004) Psychological contract and organizational citizenship behaviour in China: Investigating generalizability and instrumentality. Journal of Applied Psychology, 89(2),311-321.

Kerlinger, F. \& Lee, H. (2000) Foundations of behavioural research. Harcourt College Publishers, Orlando, FL.

Kovoor-Misra, S. (2009) Understanding perceived organizational identity during crisis and change: A threat/opportunity framework. Journal of Organizational Change Management, 22(5),494-510.

Litwin, M. S. (1995) How to measure survey reliability and validity. Sage Publication Inc. London.

Lo, S. \& Aryee, S. (2003) Psychological contract breach in a Chinese context: An integrative approach. Journal of Management Studies, 40 (4),1005-1020.

Malopinsky, L V. \& Osman, G. (2006) Dimensions of organizational change. Handbook of human performance 
technology, 262-286

Mbah, S. E. \& Ikemefuna, C. O. (2012) Job satisfaction and employees' turnover intentions in total Nigeria plc. Lagos State. International Journal of Humanities and Social Science, 2(14), 275-287.

McDonald, D. J. \& Makin, P. J. (2000) The psychological contract, organisational commitment and job satisfaction of temporary staff. Leadership and Organization Development Journal, 21(2), 84-91.

Mueller, R. (1996) Basic Principles of Structural Equation Modelling, Springer, London.

Morrison, E. W. \& Robinson, S. L. (1997) When employees feel betrayed: a model of how psychological contract violation develops. Academy of Management Review, 22,226-256.

Oreg, S. (2006) Personality, context and resistance to organizational change, European. Journal of Work and Organizational Psychology, 15(1),73-101.

Pai, H. C., Lee, S., \& Chang, T. (2011) A confirmatory factor analysis of the clinical nursing practice environment scale with hospital registered nurses in Taiwan. Journal of Clinical Nursing, 20(15-16),2344-2354.

Parzefall, M. R. \& Coyle-Shapiro, J. A. (2011) Making sense of psychological contract breach. Journal of Managerial Psychology. 26(1),12-27.

Pate, J., Martin, G., \& McGoldrick, J. (2003) The impact of psychological contract violation on employee attitudes and behaviour. Employee Relations, 25(6),557-573.

Preacher, K. J., Zhang, G., Kim, C., \& Mels, G. (2013) Choosing the Optimal Number of Factors in Exploratory Factor Analysis: A Model Selection Perspective Multivariate Behavioral Research, 48,28-56

Rayton, B. A, \& Yalabik, Z. Y. (2014) Work engagement, psychological contract breach and job satisfaction. The International Journal of Human Resource Management, 25(17),2382-2400.

Restubog, S. L. D., Bordia, P., \& Bordia, S. (2011) Investigating the role of psychological contract breach on career success: Convergent evidence from two longitudinal studies. Journal of Vocational Behavior, $79(2), 428-437$.

Robinson, S. L. \& Morrison, E. W. (2000) The development of psychological contract breach and violation: a longitudinal study. Journal of Organizational Behavior, 21,525-46.

Rousseau, D. M. (2000) Psychological contract inventory technical report. Carnegie Mellon University, Pittsburgh, PA.

Sronce, R. \& McKinley, W. (2006) Perceptions of organizational downsizing. Journal of Leadership \& Organizational Studies, 12,89-108.

Staufenbiel, T. \& König, C. J. (2010) A model for the effects of job insecurity on performance, turnover intention, and absenteeism. Journal of Occupational and Organizational Psychology, 83(1),101-117.

The Punch (2014) Oil Fields Asset Selling in Nigeria www.punchng.com retrieved on 7 September, 2018. Retrieved from http://www.google.com on 12 July, 2018

Total Nigeria PLC website: www.total.com.ng

Turnley, W. H. \& Feldman, D. C. (2000) Re-examining the effects of psychological contract violations: Unmet expectations and job dissatisfaction as mediators. Journal of Organizational Behavior, 21,25-42.

Turnley, W. H., Bolino, M. C., Lester, S. W., \& Bloodgood, J. M. (2003) The impact of psychological contract fulfilment on the performance of in-role and organizational citizenship behaviours. Journal of Management, 29(2), 187-212.

Van de Ven, A. H. \& Poole, M. S. (1995) Explaining development and change in organizations. Academy of Management Review, 20,510-540.

Williams, B. \& Brown, T. (2013) A confirmatory factor analysis of the self - directed learning readiness scale. Nursing \& health sciences, 15(4), 430-436.

Withey, M. J. \& Cooper, W. H. (1989) Predicting exit, voice, loyalty, and neglect. Administrative Science Quarterly, 34(4),521-539.

Ye, J., Cardon, M. S., \& Rivera, E. (2012) A mutuality perspective of psychological contracts regarding career development and job security. Journal of Business Research, 65,294-301.

Zagenczyk, T. J., Restubog, S. L. D., Kiewitz, C., Kiazad, K., \& Tang, R. (2014) Psychological contracts as a mediator between Machiavellianism and employee citizenship and deviant behaviors. Journal of Management, 40,1098-1122.

Zhao, H., Wayne, S. J., Glibkowski, B. C., \& Bravo, J. (2007) The impact of psychological contract breach on work-related outcomes: A meta-analysis. Personnel Psychology, 60(3),647-680.

Dr. Marian Lawrence Apoh is a lecturer in the department of Business Management, Niger Delta University, Bayelsa, Nigeria. She has a B.Sc in Accountancy, MSc in General Management, and PhD in Management (Human Resource Management). 